Island Studies Journal, Vol. 4, No. 1, 2009, pp. 25-42

\title{
Whose Bay Street? Competing Narratives of Nassau's City Centre
}

\author{
Nona Patara Martin \\ Department of History and Art History \\ George Mason University \\ Fairfax, VA \\ USA \\ nmartina@gmu.edu
}

and

Virgil Henry Storr

Mercatus Centre, George Mason University

Arlington, $V A$

USA

vstorr@gmu.edu

\begin{abstract}
Bay Street has always been at the centre of commercial, cultural and political life in the Bahama Islands. It also acts as a gateway for millions of tourists who come to Nassau, the Bahamian capital, via cruise ships every year. Not surprisingly, Bahamians and non-Bahamians have widely divergent impressions of Bay Street. The need to accommodate the tourists who are critical to the Bahamian economy has meant that Bay Street, despite its deep social significance for Bahamians, has increasingly become a tourist space. With reference to the 'sense of place' and place attachment literature, this paper traces the transformation of Bay Street and attempts to tease out the most obvious tensions between the Bay Street that Bahamians experience and Bay Street as a port of call.
\end{abstract}

Keywords: Bahamas, Bay Street, islands, Nassau, New Providence Island, place attachment, sense of place

(C) 2009 - Institute of Island Studies, University of Prince Edward Island, Canada.

\section{Introduction}

Throughout the 20th century, Bay Street was at the centre of commercial, political and social life in the island of New Providence and, indeed, within the archipelago of the Bahamas. A combination of British High Streets and US Main Streets, Bay Street Bahamas was the main commercial district in the country. Bay Street hosted the main branches of several international banks and was home to a variety of retail outlets, including clothing, jewellery and perfume stores, as well as nightclubs, restaurants and bars. It was also a key site for social and cultural expression on the island. Bay Street was the home of Junkanoo, a festival that attracted all strata of Bahamians as participants and was a part of Bahamian culture since slavery. Bay Street was also the preeminent political space within the 
archipelago. Both Parliament and the Cabinet Office were located there and, since at least the 1940s, Bay Street was seen by Bahamians as the key site for overt political protest.

Not surprisingly, Bay Street has been very much a contested space; a place where different groups vied for recognition, redress and control. Racial groups in the Bahamas, for instance, "negotiated" this place since the earliest days of the colonies, with whites using the law to limit where and when blacks could be on the street; and blacks working within and around those laws to carve out a place for themselves on the same street. Until the late 20th century, a small group of white male Bahamian merchants, known as the Bay Street Boys, wielded tremendous political power and controlled most of its major retail outlets. During this period, Bay Street was, arguably, a place where Bahamian blacks worked and shopped but rarely owned. It was also a place, however, where they resisted the economic and political hegemony of the Bay Street Boys.

The contest between the small white minority and the black majority over political and economic control of the Bahama Islands was perhaps the most important during this era; but it was not the only major contest that took place on Bay Street. Bahamian whites and blacks alike increasingly shared Bay Street with the growing number of visiting tourists each year. The main wharf for cruise ships was located such that Bay Street acted as gateway to the island for tourists who come to Nassau via cruise ships.

Although Bahamian blacks were ultimately able to carve out a space for themselves on Bay Street, it appears likely that Bahamians (both whites and blacks) will eventually lose that same space to visitors from abroad. In fact, this transformation was already occurring by the later half of the 20th century. In the early 1980s, for instance, the public market on Bay Street - which sold foodstuff to Bahamians - was replaced by a market selling straw work and souvenirs to tourists. This displacement of Bahamians from Bay Street by tourists raises several key questions; including how to balance the socio-cultural needs of people who may have no other spaces within the densely populated small island of New Providence that can claim a similarly deep social significance, against the pressing economic needs of an island nation almost wholly dependent on tourism, and with very few social and historic sites of interest to offer them outside of Bay Street. Can Bay Street remain a Bahamian space and a tourist space simultaneously? If not, should economic necessity supersede, or yield to, socio-cultural history?

On one hand, there is reason to believe that Bay Street must remain both a Bahamian and a tourist space if it is to survive as either one or the other. Although Bahamians and tourists have different and perhaps incompatible senses of place with regards to Bay Street, tourist satisfaction with Bay Street will diminish if Bahamians abandon the street. Travel guides typically describe Bay Street as a place to shop for souvenirs, but also to look at historic buildings and statues, to hear "authentic" Bahamian music, to eat "authentic" Bahamian food and to watch "authentic" Bahamian spectacles like Junkanoo. The tourist Bay Street is a place for duty free purchases and cultural voyeurism. If Bahamians stop thinking of it as a place for commerce, protest and cultural expression, Bay Street will cease being an "authentic" Bahamian space and so will no longer meet or fulfil the needs and expectations of tourists. On the other hand, the version of Bay Street that Bahamians tout, and that 
tourists experience, is less than authentic. As such, it is possible that Bay Street cannot remain an essentially Bahamian space if it is to continue to develop as a tourist magnet and enclave.

Using the sense of place literature, this paper traces this transformation of Bay Street as a way of teasing out the tensions between maintaining Bay Street as an "authentic" Bahamian experience and growing Bay Street as a critical port of call. Section II outlines the sense of place and place attachment literature as it relates to (especially island) tourism. Section III chronicles the transformation of Bay Street over the course of the 20th century. Section IV discusses the competing narratives that Bahamians and non-Bahamians tell about Bay Street. The paper ends by offering some concluding remarks.

\section{Islandness, Tourism and Sense of Place}

The relationships and connections that people have with the places that they visit, and in which they live and work, has been the topic of study for several disciplines (e.g. Hay, 1998; Relph, 1976; Vorkinn \& Riese, 2001). Environmental psychologists rely on three related concepts to describe a person's connection to a particular milieu: (a) place attachment: the affection or bond that people feel for a particular environment; (b) place identity: that part of a person's identity that people define in relation to a particular place; and (c) place dependence: a person's sense of how well a particular place can satisfy his/her desires compared to other places (see Altman \& Low, 1992; Proshansky, 1978; Stokols \& Shumaker, 1981, respectively). Human geographers deploy the concept of sense of place - which encompasses the three related phenomena of place attachment, identity and dependence - and can use this to describe the attitudes, beliefs and memories that people associate with a particular place.

Key to understanding the connectivities between people and place are the works of Yi-Fu Tuan (e.g. Tuan, 1980). "Place," Tuan (1975: 152) writes, "is a centre of meaning constructed by experience." To know a place fully, he explains, one must possess more than indirect encyclopaedic knowledge of, or about, it; one must know more than a collection of facts about a place's location, size, population, weather patterns, languages spoken, religions practised, or industries in operation. Knowing a place fully means not only knowing it through the "eyes and mind"; it also means knowing it through experience: "as one person knows another" (Tuan, 1975:152). Places are known both abstractly and experientially. As he writes:

"[P]laces are constructed out of such elements as distinctive odours, textural and visual qualities in the environment, seasonal changes of temperature and colour, how they look as they are approached from the highway, their location in the school atlas or road map, and additional bits of indirect knowledge like population or number and kinds of industries. Within the middle range places are thus known both directly - through the senses - and indirectly through the mind" (ibid.: 152153). 
Steele (1981) offers a similar formulation. Sense of place, for him, describes "the way [place] affects our life and the ways in which we create our own" (Steele, 1981: ix). For Steele, a person not only perceives, or experiences, a place but also partakes in its creation. Of course, some settings "have a strong spirit of place that acts in a powerful, predicable manner on everybody who encounters them" (Steele, 1981: 13). Yet, a person's perception and awareness are vital parts of what makes up a person's sense of place. As Steele (1981: 33) writes:

"[W]hen people come to a setting, they usually do not arrive empty-handed, open to whatever turns up there. They almost always bring a good deal of 'baggage' with them that influences how they perceive, use and feel about the setting."

Understanding differences in the strength of a people's connection to a place and the nature of their place relationships is key to understanding their different attitudes toward changes that happen to a place over time. Additionally, focusing on differences in sense of place can be useful for understanding differences in people's outlooks, dispositions, political activism and community engagement. Focusing on differences in sense of place is especially useful to understanding the reason behind landscape conflicts (that is, differences over how a space should be used, maintained and altered). Jorgensen and Stedman (2001), for instance, have demonstrated that sense of place can explain people's attitudes toward their properties. Similarly, Kaltenborn (1998) found that differences in the strength of sense of place explained different reactions to changes in the environment amongst residents of the Svalbard (Spitsbergen) archipelago, Norway.

Paying attention to differences in sense of place, however, is not only fruitful for understanding the different reactions of residents to socio-cultural and environmental change. Because place relationships are likely to differ so much between tourists and locals, looking to sense of place can be particularly useful in helping us understanding the differences across these groups in their attitudes towards a place and reactions to actual, and proposed, changes. Hay (1998), for instance, has suggested that there can be large differences in the strength of place attachment between tourists and locals. The local Maori in the Banks Peninsula, New Zealand, he found, had a more rooted sense of place than tourists, who had a more superficial sense of place. Similarly, Kianicka et al. (2006) have argued that differences in sense of place can explain why locals and tourists disagree on measures aimed at developing, conserving or restoring a particular built environment. Examining locals' and tourists' sense of place in a Swiss alpine village, they found that:

"[V]ariations in the evaluation of landscape development between residents and non-residents can be ascribed to their distinct sense of place, which is in turn due to the different meanings they attribute to the same place characteristics" (ibid.: 62).

Locals' sense of place is typically formed by their experience of a place as they go about their daily living, and so their memories of a place may date back to childhood. The tourists' sense of place, on the other hand, is shaped by "the aesthetics and characteristics of the place" as they experience it in the context of time-bound leisure activities (ibid.). What tourists do in a place (as individuals) is the basis of their place relationships, rather 
than their existence and social interaction within the place, as is the case for residents. Kianicka et al. (2006) also argued that differences in the strength of sense of place were not as important as Hay assumes. Tourists might develop a very strong sense of place but it would nonetheless be different than the sense of place of residents.

Islands engender a unique and often particularly strong sense of place amongst residents. As Stratford (2008: 171) writes:

"[I]slands are constitutive of strong place-based identifications: emotional geographies that may be described as islandness; something that is affective and ontological."

Similarly, Baldacchino (2005: 35) argues:

"[S]mall islands are special because their 'geographical precision' facilitates a (unique) sense of place; a deployment towards the sea and a maritime destiny that facilitates trade; and an obvious sense of alterity with the rest of the world beyond the horizon."

The ontological import of islandness can be both an advantage and a challenge for heritage managers as they work through land use conflicts and proposals to preserve or alter a particular space, especially as it relates to tourism. It is an advantage because islanders recognize that being closed is not an option. "Autarkist development strategies," as Baldacchino (2005: 35) writes, are off the table. Islandness poses a challenge, however, because the place attachment that tourists develop is likely to be quite different from the sense of place that islanders possess.

Although the lens of sense of place has been used to explore differences in the attitudes and place relationships between tourists and locals in other contexts, it has, to our knowledge, not yet been applied to the Bahamas. This is a glaring hole in the literature on tourism in the Bahamas. Tourism is by far the most important industry in the country. It is responsible for over $60 \%$ of the economy providing US $\$ 1.678$ billion in revenue annually and bringing 4.2 million tourists to the Bahamas (over 12 times the Bahamas' population) to the country every year (Bahamas Department of Statistics, 2005). As noted above, most of these tourists visit Nassau (the capital) and all but a few spend some time on Bay Street. No wonder, then, that Bay Street is a key resource that has played a critical role in both the Bahamas' tourist trade and its socio-cultural development. If differences between locals' and tourists' sense of place exist (either in the strength of their place relationships or the meanings that they attach to them), then this might help us understand why Bay Street changed as it did during the 20th century, how it continues to change, and the manner in which the locals and tourists may have reacted to those changes. Additionally, understanding the differences between locals' and tourists' sense of place might provide some insight into whether heritage managers should work to reverse or to further encourage the changes to Bay Street that have occurred over that period. A first step in getting at these sorts of questions, however, requires addressing some of the key changes 
to Bay Street that have happened during this period and discussing how those changes have impacted the narratives of Bay Street constructed by locals and tourists.

\section{Locals' Perception of Bay Street and the Loss of Space to Tourists}

As noted above, throughout the 20th century, Bahamians were prone to regard Bay Street as the centre of their country's civic, social and economic life. Bay Street, however, changed radically during this period. Some physical changes were significant, but the socio-political transformation of that space was perhaps even more profound. For instance, the large Georgian styled structures in Parliament Square which were built in the early 1800s and now house the House of Assembly, the Senate and the office of the Leader of the Opposition still look very much as they did centuries ago. In 1905, a large white statue of young Queen Victoria sitting on her throne flanked by two canons was added to the courtyard; in mid-century, the buildings were painted the now familiar pink trimmed with white: a pattern which characterizes many government buildings in the Bahamas.

Many of the events that signalled the political movement of the Bahamas from a minority controlled British colony to a majority controlled independent country took place within and outside these stone structures. The 1942 riot on Bay Street, which began as a protest outside the Colonial Secretary's Office across from Parliament Square, was the first sign of political awakening amongst the black majority in the Bahamas (Saunders, 1985). On June 1, 1942, disgruntled labourers associated with a large project to construct two U.S. military bases on New Providence (the country's main island), marched to Bay Street carrying clubs and sticks "after their continual and by then quite loud demands for higher wages were met with patronizing replies and admonishments to return to work" (Martin \& Storr, 2007: 75). When their demands were yet again met with condescension, a portion of the crowd began to take their frustrations out on Bay Street, moving down the street breaking windows and looting stores until the Cameron's Highlanders, a group of Scottish soldiers who were stationed in Nassau, were brought in to clean the street of protestors. As we argued elsewhere:

"[T]he 1942 riot demonstrated to both Bahamian blacks and the oligarchs - who were known collectively as the 'Bay Street Boys' - that Bay Street was vulnerable. Indeed, the riot showed quite clearly that the hold the merchant princes had on the Bahamas was far from complete and unassailable. The majority black population in the Bahamas could literally dismantle the edifices of minority white rule, if sufficiently provoked" (Martin \& Storr, 2007: 74).

In 1965 another event, not as violent or destructive but just as significant in the political life of the Bahamas, occurred outside Parliament on Bay Street. On Tuesday, April 27, a large and noisy crowd of Progressive Liberty Party (PLP) supporters gathered outside the House of Assembly. Inside the Assembly, the House was debating and would subsequently reject the PLP's motion to have the constituencies redrawn under the direction of the United Nations. In protest, Lynden Pindling, then Leader of the Opposition, denounced the Bay Street Boys who controlled the majority of the seats within the Assembly, took hold of 
the speaker's ceremonial mace, and threw it out of the window to the waiting crowd below (Nassau Guardian, 1965). Milo Butler, a leading figure in the PLP, grabbed and tossed out the quarter-hourglasses that the speaker used to keep time. The PLP members of the House then stormed out. This was "... a defiant act by the PLP and ultimately a defining one for the Bahamian people" (Martin \& Storr, 2009). If the 1942 riot was the first sign of a political awakening amongst Bahamian blacks, Black Tuesday, as it would come to be called:

"... was definitive proof that blacks in the Bahamas were prepared and able to stand up to the white ruling minority ... They had been warned by Bay Street not to protest, to stay away from Parliament. Still, large numbers had gathered on Bay Street. Black Tuesday was also proof that the PLP was the 'Negro's party' (as its propaganda vehicle, the Herald, repeatedly claimed)" (ibid.).

Two years after Black Tuesday, the PLP won a majority control in the Assembly, changing the face of politics in the Bahamas.

If it is fair to say that Bay Street shifted from a white controlled space to a black controlled space (at least politically) in the 20th century, it is also possible to argue that, during that same period, Bay Street increasingly became a tourist space. Tourism was not always the mainstay of the country. Illicit industries such as piracy and smuggling, and more mundane industries like agriculture, were at one time or another major sources of income for Bahamians (Storr, 2004). Illicit industries, however, do not tend to be sustainable; and poor soils are not particularly suited for agriculture. While the Bahamas may be blessed with clear blue water, powder fine white (and in some places a delicate pearl coloured) sand, and temperate weather, they are also cursed with very thin soil, no predictable rainy season, a place in the hurricane path and, thus, a very short growing season. Poor soils and outside market competition (especially from Cuba and Hawaii) marked the decline of the pineapple industry by the early 1900s. The sponge market was all but destroyed by blight at the end of 1938 (Public Records Office, 1974); and World War II saw the end of the market for sisal, until then a very profitable crop.

Tourism, albeit at small levels, has always been a part of the Bahamas' history. Tourism's potential as an industry was recognized in the early 1740's by Peter Henry Bruce (1782) who described the Bahamas as enjoying:

"[the most] serene and the most temperate air in all America ... [and is] ... therefore no wonder the sick and afflicted inhabitants of those climates fly wither for relief, being sure to find a cure here" (Bruce, 1782: 34).

Since Bruce's visit, it comes as no surprise that the Bahamas has tried to capitalize on its purported idyllic assets. The Nassau Guardian shows advertisements for bed and breakfast type lodgings as early as the 1830s. The first major hotel in the Bahamas, The Royal Victoria, was completed in 1861. In 1900, the Hotel Colonial, another major hotel which is the forerunner to the current British Colonial Hilton, opened on one end of Bay Street. 
By the 1950s, the Bahamas was already the playground for wealthy American, Canadian and British tourists. Just over 30,000 visited the island each year during this period. Sir Stafford Sands, the colony's first Minister of Tourism, however, transitioned the Bahamas from a winter getaway to a year-round tourist site. Within a decade, over 250,000 tourists were visiting the island each year (Bahamas Development Board, annual reports). Moreover, most of the tourists went from being stay-over visitors to cruise ship visitors. In 1969, Nassau Harbour was deepened to allow it to accommodate the largest of cruise ships and to allow up to nine ships of similar size to dock simultaneously at Prince George's Wharf, just north of Bay Street (Cleare, 2007). By 1991, cruise ships accounted for two million visitors annually to the Bahamas.

Beyond the changes mentioned above, Bay Street became a tourist space in a variety of other ways. Even Junkanoo, which has been described as the quintessential Bahamian experience and plays such an important role in Bahamians' attachment to Bay Street, has been altered by the growth of tourism. As Craton and Saunders (1998: 266) write, traditional Junkanoo celebrations:

"... were vivid and exciting spectacles for the tourists on their Bay Street balconies, perhaps for the very reason that they teetered on the edge of being uncontrolled".

By the late 1930s, however, Junkanoo on Bay Street had become "much better ... controlled" and, as a result, "a magnet for tourists yet, at the same time, regarded as the most important of all manifestations of Bahamian culture" (ibid.: 266). By 1940, "the Tourist Board adopted Junkanoo as a tourist attraction" (ibid.: 488). This has remained the case.

Not surprisingly, stores on Bay Street increasingly began to cater to this tourist explosion, selling souvenirs and duty-free goods. Small scale entrepreneurs opened stalls along Bay Street and in its various market locations. That the Bahamian-focused Public Market located on the west end of Bay Street was eventually replaced when it burned down with the tourist focused Straw Market and the new headquarters for the Ministry of Tourism speaks to volumes about the changing nature of Bay Street.

The Public Market, a large stone structure on Bay Street facing Market Street, was built in 1901, replacing the wooden stalls that previously comprised the market. At the entrance was the butchers' section; at the back (nearest the sea) was the fish market; and, in a corner of the market just outside where the fishing boats tied up next to the fish market, was a produce exchange and fruit and vegetable stalls (Moseley Moss, 1999). "Every household in Nassau had dealings with the Market", wrote Moseley Moss (ibid.: 178). In the 1920s and 1930s, however, vendors selling crafts made from straw and sisal for tourists began selling their wares in Rawson Square across from the Parliament Buildings, and along Bay Street. As Craton and Saunders (1998: 584) write: 
"In the late 1930s and 1940s, enterprising vendors from the fruit and vegetable market ... greatly expanded the trade to satisfy tourist demand by sewing and fashioning at their stalls the rolls of palm straw plait ... into mats, baskets and hats".

The vendors moved to a space created for them in Rawson Square in 1959 and remained split between there and the two other straw markets: the one across from the Kelly's lumber yard where the Churchill building now stands, and one in the old Customs building, which would become the home of the Junkanoo expo.

In spite of its significance and the presence of two other straw markets on Bay Street, the Public Market was not rebuilt when it was destroyed by fire in 1974. Instead, in 1983, the government renovated the structure, turning it into a straw market, and thus consolidating all the Bay Street straw markets. The market was also put under the auspices of the Ministry of Tourism. The stalls were smaller and straw vendors had to pay a small fee to rent a stall; but they were now together under one roof. Locals lost their market; they would have to shop elsewhere. But tourists gained a bazaar: a place to buy handicrafts, straw works and cheap t-shirts.

The practice of public officials to favour tourist over local uses of Bay Street had by then become a well established trend. Those cultural practices that remained on Bay Street were co-opted for tourist consumption. Businesses that once catered to locals began catering to tourists. Bay Street increasingly became a place where Bahamians worked, and decreasingly a place where they shopped and played. The proliferation of bank branches around the island meant that many Bahamians could, and now did, bank nearer to their homes. The growth of alternate commercial areas which attracted Nassuvians, like Palmdale and the development of indoor shopping centres like Town Centre Mall and the Mall at Marathon in the latter part of the century, meant that there were competitive shopping alternatives to Bay Street for locals.

This transformation of Bay Street, coupled with the remaining significance of Bay Street for Bahamians as a place of protest and cultural celebration, makes for a complex place relationship between Bahamians and Bay Street. Bahamians still maintain a strong place attachment and place identity vis-à-vis Bay Street; but, at the close of the 20th century, they were being drawn elsewhere to shop and play. Tourists, however, forge an altogether different relationship. For them, Bay Street is a gateway to a heavily themed island paradise; a place to buy cheap trinkets to remember their time away and duty-free luxury goods like perfume, leather bags and jewellery; a place to gaze at historical buildings and Bahamians as they go about their daily business and perform during their cultural festivals. By the end of the 20th century, Bay Street was for tourists a place where they were catered to and served; but it was ceasing to be a place where they could observe Bahamian performativity, because by then Bahamians were 'living' and 'spending their time' elsewhere. Can Bay Street, however, serve its function as a tourist space - even if of a particular type - if it ceases to be a key site for Bahamians? Is preserving Bay Street as a resource for locals critical to its continuing to effectively serve as a resource for tourists? Does Bay Street have to serve two masters - tourists and locals alike - if it is to serve 
either effectively? The ways that Bahamians market Bay Street, and the narratives that tourists tell about their experiences in that space, offer possible answers to such questions.

\section{Bay Street and Brochure Discourse}

In her work $A$ Small Place, Kinkaid (2000) critically highlights the disconnect between what tourists see and how locals live on small islands. Similarily, Strachan (2002) has argued that Bahamian governments engage in what he describes as a brochure discourse where they market the Bahamas as paradise and themselves as the keepers of that paradise. As he writes, however:

"[T]his brochure discourse offers an interesting version of 'paradise' to the eyes and pocketbook of the visitor ... [with] smiling black 'natives' ... ready to serve, ready to please, gesturing with their hands for the viewer to come and join in the fun" (Strachan, 2002:1).

Streets lined with brightly painted colonial style buildings, police officers dressed in colonial era uniforms wearing white gloves and directing traffic, taxi drivers dressed in long sleeve shirts and loud neckties, waiting to take you back to the hotel, and smiling straw vendors, hair braiders and fruit and vegetable sellers hawking their wares and services ... such is the local cultural context that appears in television commercials and marketing campaigns. According to Strachan (ibid.: 5):

"... the word "paradise" comes to signify much more than the first habitation of Adam and Eve once it is adopted to describe the colonized Caribbean. At various periods in the past 500 years, paradise has been associated with notions of the primitive, innocence, savagery, and a lack of civilization, as well as of ignorance and nakedness, health and happiness, isolation from the rest of the world and humanity, timelessness, nature's beauty and abundance, life without labour, human beings' absolute freedom and domination over nature as God's stewards on Earth, and connections of paradise with concepts of wild pleasure, perpetual sunshine, and leisure".

The problem with this brochure discourse, as Strachan notes, is that it is partial and not authentic. The underlying socio-economic reality in the Bahamas - amongst other issues is quite different. That Bay Street is a contested space never makes its way into brochures or travel books. That poverty, crime and HIV/AIDS continue to be serious problems in the country (e.g. Bell, 2006) is not portrayed in TV commercials and print advertisements. As Strachan (ibid.: 1) again writes:

"[T]he world [described in the brochure discourse] has as much authenticity for indigenous residents as would a stage or movie backdrop". 


\section{The Bay Street Story to Consume}

What, then, is the story of Bay Street that locals sell and tourists consume? Baker's Lonely Planet: Bahamas, Turks and Caicos, for instance, describes downtown Nassau, including Bay Street, as:

"[A] compact historic district whose many well-preserved $18^{\text {th }}$ and $19^{\text {th }}$ century buildings evoke the colourful past" (Baker, 2001: 162).

Commenting on Parliament Square, Baker suggests that "it's amazing to think that these three tiny buildings are the centre of government!" Baker (ibid.: 164) points to a number of quaint Bay Street landmarks including the "colonial-era" British Colonial Hotel, the Royal Bank of Canada's "grandiose stone structure" built in 1919 and the "notable edifice" of the Masonic Temple "dedicated in 1885." When describing the straw market where you can buy "everything from straw-work to t-shirts" and "watch craftspeople whittling wood or weaving straw," he tells of 'Aunt Di', a market matriarch who "has been selling straw since the early 1930s (from the age of 10)." Baker's Bay Street is a picturesque little city centre, with lovely historical structures and colourful characters.

Moore's Pelican Guide to the Bahamas offers a similar account:

"The architecture of Nassau," he writes, "offers far and away the finest sightseeing treat in all of Nassau" (Moore, 1999: 80).

He goes on to speak of "picturesque gingerbread-bedecked one room homes" and "impressive pink buildings" on and around Bay Street. Just strolling around the downtown area is highly recommended. Of Bay Street, Moore (ibid.: 80) writes:

"[D]uring the rare times when sidewalks are not jammed with tourists, window shopping beneath the tin roofs covering the walkways is a pleasant diversion... [T] his short walk affords local colour not to be missed" (ibid.).

The "many intriguing small shops" on Bay Street will sell you everything from expensive French perfumes at half the price one would pay for them in the U.S., to "mounds of treasures and trifles" (ibid.). Or, Moore (ibid.: 122) recommends, visit "Nassau's famous Straw Market" where you can bargain with the market women for their stock of "funny hats, bright place mats, bags of every shape and size, dolls, toys, and tacky souvenirs." Moore's Bay Street is presented as a charming, little, primarily commercial space that has a little something for all.

Both Porter and Prince (2000) and Derrick (2001) offer similar descriptions of Bay Street and the Bahamas. The country's government and citizenry, who depend so heavily on tourism, want tourists to buy a particular version, or brand, of Bay Street; the same one that the Bahamas travel guides are promoting. Indeed, they have worked hard to make such a narrative consistently plausible and persuasive. Throughout the 20th century, tourists seem to have bought into and helped to perpetuate that narrative. 
As a 1939 traveller to Nassau recounts, for instance:

"Nassau is a darling place. ... the market place ... was full of stalls where soft spoken Negroes were selling all manner of hats, and many kinds of baskets. But we did well to move onto Bay Street for shopping, because it is a miniature Bond Street and was alive with amazing travellers from the two huge liners" (Cousin, 1939).

Similarly, as a 1957 visitor notes:

"[T]he visitor skilled in trading techniques may acquire mats, bags, pocketbooks and hats at native straw markets on Prince George's Dock and Bay Street for surprisingly small sums" (Hamallan, 1957).

A tourist who visited Nassau in 1959 echoes these other visitors. Speaking of his time in Nassau, he writes:

"Bay Street, with its bargains in booze, British woollens, Irish and Hong Kong linen and French perfume, can make a dent in a wallet; but the climate is there to be enjoyed by anyone. And, if it's bongo drums and the biological gyrations of the native dancers that interests you, admission to the native calypso night clubs, such as the Cat and the Fiddle [both on Bay Street], is only \$1” (Thompson, 1959).

Yet another tourist, who vacationed in Nassau in 1961 offers an equally compelling account: "The launch," she writes, "puts her passengers ashore at the foot of Rawson Square, a square ... in the very centre of Nassau." Recall that, in 1961 when she visited, straw vendors would have still been situated in stalls within the square several blocks from the Public Market site where the Straw Market was eventually relocated. She offers a vivid account of the sights and sounds of Rawson Square:

"One needs only to listen to know what there is to do, see and buy. Native voices call out a choice of things to do and buy....'Nice straw hat, lady?' So call out the women from their stalls in the Rawson Square straw market. Bags, baskets and hats of myriad sizes, shapes and decorative treatments are displayed in the yard. These straw weavers work as they sell; and; if one does not see just what he [sic] wants, he can have it made to order" (Freeman, 1961).

The Bay Street she describes is a place where colourful local hawkers traffic their wares.

Bay Street has been celebrated as a charming place: " $18^{\text {th }}$ century buildings are noted for their Bahamian architecture" (Isaacs, 2004: 50). Bay Street, for tourists, was as a place where old meets new. Similarly, a 1984 tourist describes Bay Street as a quaint place, with a distinct old world charm. He reports that: 
"[T]he British colonial atmosphere survives, especially along Bay Street and its white colonnaded government buildings" (Kreiter, 1984).

For this visitor, the statue of Queen Victoria that overlooks Rawson Square at the centre of Bay Street is not a shadow of imperial control, as some residents may interpret it. Instead, the "straight laced" queen somehow "completes the scene" (ibid.). Bahamian visitors understand that this old world charm is accessible to them for a price; and that this price is not firmly fixed. On Bay Street, one can "enjoy haggling over the price of homemade hats, purses, baskets and you-name-it at the straw market" (ibid.). Not only could you purchase trinkets and souvenirs; even a bit of the living culture could be obtained at a price. It is on Bay Street, "where little girls may offer to sing [visitors] a song for a quarter; and where the best way to get around is by horse-drawn carriage" (ibid.)

Contemporary reports from tourists are similar. TripAdvisor's online review site, for instance, contains a handful of reports from tourists who visited the Bahamas. Those who mention Bay Street in the accounts emphasize the deals to be had. For instance, a visitor from Los Angeles, California, writes:

"[W]e wanted to see the beautiful surrounding areas of Nassau as well as Bay Street ... we took a walk thru [sic] the port to go to Bay Street. Lots of shops and good deals" (TripAdvisor, 2008).

Another visitor writes:

"[T]he liquor stores are cheap and the perfume stores are great! I stocked up on everything plus got all my souvenirs. There are many high end stores on Bay Street as well ... The jewellery at Discount Warehouse is fantastic and priced well. I love the Bahamas!!!!"” (TripAdvisor, 2004).

Thus, most contemporary and historical accounts tend to gloss over the problems in the Bahamas, adopting and perpetuating the brochure discourse surrounding tourism in the Bahamas. The Bay Street that visitors see is a Bay Street of straw vendors, swanky dutyfree shops and quaint centuries-old buildings. The Bay Street of protest and political theatre, the Bay Street of cultural expression, the Bay Street of deep social significance to Bahamians, does not form a part of their narrative, beyond what can be neatly packaged and conveyed through sightseeing tours and maps of local colour.

That this (arguably successful?) brochure discourse stresses an inauthentic form of Bahamian life would seem to suggest that preserving Bay Street as a local resource and continuing to utilize it as a tourist enclave may very well be at odds. By and large, tourists are not attracted to Bay Street because it is a space for protest and cultural expression. Instead, they are attracted to Bay Street because of its quaintness, old world charm, and souvenirs. That Bahamians have been abandoning Bay Street for other spaces away from the city centre suggests that the complete transformation of Bay Street into a tourist space may be inevitable. The confluence of circumstances that made Bay Street the centre of economic, political and social life on the island and within the Bahamian archipelago are unlikely to exist for much longer; nor are they likely to be replicable elsewhere. Preserving 
buildings is not enough to maintain Bay Street as a living resource for Bahamians. Yet it remains unclear what, if at all, could be done beyond preserving buildings.

\section{Future Prospects}

Current debates around the future of Bay Street seem to acknowledge, at least implicitly, that Bay Street may not be serving either of its two key constituencies well. As noted earlier, Bahamians were shopping and playing elsewhere. Although tourists, especially cruise ship visitors, may have been offered very few alternative places to go to, there was a growing disconnect between the Bay Street promised by the brochures and the Bay Street that they experienced. As one visitor complained, the island and its main street were "overpriced, dirty" (MyTravelGuide, 2006). Similarly, in a letter to the editor, a Bahamian wrote:

"What a dump!!... The rundown, dilapidated look [of Bay Street] is so obvious. Historical buildings, such as the old Hatchet Bay Plantation building, is [sic] in an acute state of disrepair ... Even some government buildings on Bay Street are in need of repairs" (Percentie, 2004).

Not surprisingly, recent Bay Street "revitalization" drives have focused on addressing these basic concerns. The Downtown Improvement Initiative, for instance, is a plan of action developed by some 200 stakeholders, funded mostly by special assessments of all downtown properties. Its goal is to "enhance its retail offering" with "specialty and signature stores," and to address key concerns such as:

"[T]he transportation of prisoners to downtown courts, the jitneys that stop on Bay Street, and what should be done with business and building owners who allow their buildings to deteriorate into an unkempt state" (ibid.).

All this in an attempt to make Nassau's down town Bay Street a "living waterfront" attractive to tourists (Brennen, 2006). Indeed, this plan was not so different from the "master plan" introduced two years earlier which attempted to address resident concerns about "public transportation and parking along Bay Street", but primarily focused on changes that would entice and encourage residents to make Bay Street the heart of a "city of romance" (Matthews, 2004). These initiatives, and the debates surrounding them, suggest that heritage managers are comfortable with Bay Street increasingly being given over to tourist purposes.

\section{Conclusion}

We understand that there is a diversity of local and tourist types and interests; further research would need to move away from this rather simplistic rendition of these two categories. However, differences between the locals' and tourists' 'sense(s) of place' are quite dramatic. Most tourists develop, as they are encouraged to do, a thin conceptualization of Bay Street and the Bahamas as paradise. The brief and heavily 
regulated interactions that cruise ship visitors have with Bay Street do little to contradict the discourse which may have made Nassau an attractive destination in their eyes in the first place. Indeed, cruise ship operators, travel companies, locals, and government officials in the Bahamas are quite complicit in painting and maintaining this "picture of paradise" for tourists.

Increasingly, Bahamians and their governments have worked to transform Bay Street into a tourist space and market. This transformation is well nigh complete. Such a tourist space, however, complicates the place relationship/s that Bahamians have with Bay Street and raises a number of critical questions about its future. Will the strength of Bahamians' place attachment and place identity wane as their place dependence with respect to Bay Street diminishes? Can Bay Street remain such a prominent place in the Bahamian psyche if it only continues to be a central place in the lives of Bahamians who work on, or near, it?

So long as Parliament is on Bay Street, it would presumably remain a place where Bahamians go to protest and seek redress. However, if Bahamians' sense of place regarding Bay Street declines, is there yet a case to be made for Bay Street to persevere as the key national space for cultural expression and social engagement? Does preserving Bay Street's heritage - so that tourists can have things to do and see in a country so heavily dependent on tourism - invest that enterprise with more, or less, vigour? Is it less 'authentic' compared to efforts to preserve its heritage for locals? These are important challenges to consider.

\section{References}

Altman, I. \& Low, S. (eds.) (1992) Place Attachment: Human Behaviour and Environment, Vol. 12, New York, Plenum Press.

Bahamas Department of Statistics (2005)

http://statistics.bahamas.gov.bs/download/010419000.pdf.

Baker, C.P. (2001) Bahamas, Turks \& Caicos: Includes Hundreds of Dive and Snorkel Sites, Oakland CA, Lonely Planet Publications.

Baldacchino, G. (2005) 'The Contribution of Social Capital to Economic Growth: Lessons from Island Jurisdictions', The Round Table: Commonwealth Journal of International Affairs, Vol. 94, No. 378, pp. 35-50.

Bell, K. (2006) 'Youth Crime and Violence', $6^{\text {th }}$ Commonwealth Youth Ministers Meeting: Thematic Papers, London, Commonwealth Secretariat, pp. 41-55.

Brennen, C. (2006) 'Revitalization to make Nassau 'Marina Magnet', The Tribune, July 24.

Bruce, P.H. (1782) Memoirs of Peter Henry Bruce Esquire: A Military Officer, London, printed for the Author's widow. 
Cleare, A.B. (2007) History of Tourism in the Bahamas: A Global Perspective, Bloomington IN, Xlibris Corporation.

Cousin E. (1939) 'Traveller Stops at Nassau on Winter Cruise', Chicago Daily Tribune, February 19, F2.

Craton, M. \& Saunders, G. (1998) Islanders in the Stream: A History of the Bahamian People from the Ending of Slavery to the $21^{\text {st }}$ Century, Athens GA, University of Georgia Press.

Derrick, R.C. (2001) Bahamas for Dummies, New York, Hungry Minds.

Freeman, H.B. (1961) 'The Song of the Bahamas: Exotic Sounds as well as Sights Entertain Nassau Visitors', New York Times, April 9, XX7.

Hamallan, L. (1957) 'Bahama Island Shopping: Bargains Abound There, and Owners may even Commute', New York Times, February 17, X36.

Hay, R. (1998) 'A Rooted Sense of Place in Cross-Cultural Perspective', Canadian Geographer, Vol. 42, No. 3, pp. 245-266.

Isaacs, A. (2004) Travel Trade Gazette UK \& Ireland No. 2465, December, p. 50.

Jorgensen, B.S., Bradley S. \& Stedman, R.C. (2001) 'Sense of Place as an Attitude: Lakeshore Owners' Attitudes toward their Properties', Journal of Environmental Psychology, Vol. 21, No. 3, pp. 233-248.

Kaltenborn, B.P. (1998) 'Effects of Sense of Place on Responses to Environmental Impacts: A Study among Residents in Svalbard in the Norwegian High Arctic', Applied Geography, Vol. 18, No. 2, pp. 169-189.

Kianicka, S., Buchecker, M., Hunziker, M. \& Müller-Böker, U. (2006) 'Locals' and Tourists' Sense of Place: A Case Study of a Swiss Alpine Village', Mountain Research and Development, Vol. 26, No. 1, pp. 55-63.

Kincaid, J. (2000) A Small Place, London, Farrar, Straus and Giroux

Kreiter, T. (1984) The Saturday Evening Post, (November), p. 92.

Martin, N.P. \& Storr, V.H. (2007) 'I'se a Man': Political Awakening and the 1942 Riots in the Bahamas', Journal of Caribbean History, Vol. 41. Nos. 1-2, pp. 72-91.

Martin, N.P. \& Storr, V.H. (2009) 'Demystifying Bay Street: Black Tuesday and the Radicalization of Bahamian Politics in the 1960s', Journal of Caribbean History, Vol. 43, No.1, forthcoming.

Matthews. M. (2004) 'Rotarians given Details of Bay Street Redevelopment', Nassau Guardian, August 3, B1 
Moore, J.E. (1999) The Bahamas 2000, London, Pelican Publishing.

Moseley Moss, V. (2001) Reminiscing: Memories of Old Nassau, edited by R.G. Lightbourn, Hong Kong, published by the author.

MyTravelGuide (2006) www.mytravelguide.com/hotels/profile-18653703-

Bahamas_Nassau_British_Colonial_Hilton_Nassau.html.

Nassau Guardian April 28, 1965.

Percentie, L. (2004) 'Filthy Nassau', Nassau Guardian, August 16, I0.

Porter, D. \& Prince, D. (2000) Frommer's Complete Bahamas 2000, New York, Wiley.

Proshansky, H.M. (1978) 'The Self and the City', Environment and Behaviour, Vol. 10, No. 2, pp. 147-169.

Public Records Office (1974) The Sponging Industry: A Booklet of the Exhibition of Historical Documents held at the Public Records Office, London, Public Records Office.

Relph, E. (1976) Place and Placelessness, London, Pion

Saunders, G. (1985) 'The 1942 Riot in Nassau: A Demand for Change?', Journal of Caribbean History, Vol. 20, No. 2, pp. 117-146.

Steele, F. (1981) The Sense of Place, Boston MA, CBI Publishing Company.

Stokols, D \& Shumaker, S.A. (1981) 'People in Places: A Transactional View of Settings' in J. Harvey (ed.) Cognition, Social Behaviour, and the Environment, Hillsdale NJ, Erlbaum, pp. 441-448.

Storr, V.H. (2004) Enterprising Slaves and Master Pirates: Understanding Economic Life in the Bahamas, New York, Peter Lang.

Strachan, I.G. (2002) Paradise and Plantation: Tourism and Culture in the Anglophone Caribbean, Charlottesville VA, University of Virginia Press.

Stratford, E. (2008) 'Islandness and Struggles over Development: A Tasmanian Case Study', Political Geography, Vol. 27, No. 2, pp. 160-175.

Thompson, J.H. (1959) 'The Tribune's Travel Guide: Nassau Trip Can Be Lazy, Carefree Fun Island Offers Sun, Sea, Surf', Chicago Daily Tribune, October 11, H2.

TripAdvisor (2004) www.tripadvisor.com/Attraction_Review-g147416-d147522-ReviewsBay_Street-Nassau_New_Providence_Island_Bahamas.html.

TripAdvisor (2008) www.tripadvisor.com/Attraction_Review-g147416-d147522-ReviewsBay_Street-Nassau_New_Providence_Island_Bahamas.html. 
Tuan, Y.F. (1975) 'Place: An Experiential Perspective', Geographical Review, Vol. 65, No. 2, pp. 152-153.

Tuan, Y.F. (1980) 'Rootedness versus Sense of Place', Landscape, Vol. 24, No. 1, pp. 3-8.

Vorkinn, M. \& Riese, H. (2001) 'Environmental Concern in a Local Context: The Significance of Place Attachment', Environment and Behaviour, Vol. 33, No 2, pp. 249363. 